\title{
PERAN LINGKUNGAN KELUARGA DAN EFIKASI DIRI YANG MEMOTIVASI MAHASISWA UNTUK MENJADI YOUNG ENTREPRENUER
}

\author{
Munawir Nasir*1, Muh. Haerdiansyah Syahnur ${ }^{2}$ \\ Jurusan Manajemen, Fakultas Ekonomi dan Bisnis, Universitas Muslim Indonesia Makassar ${ }^{1,2}$ \\ e-mail: munawirnasir.hamzah@umi.ac.id"1 ${ }^{* 1}$, haerdiansyah@umi.ac.id ${ }^{2}$
}

\begin{abstract}
Abstrak
Tingkat pengangguran terbuka (TPT) lulusan universitas dengan rentang sarjana semakin mengkhawatirkan, hal ini banyak terjadi disebabkan bertambahnya angkatan kerja yang tidak terserap sepenuhnya oleh lapangan pekerjaan. Observasi awal yang dilakukan kepada 50 mahasiswa yang diwawancarai tentang minat dan motivasi menjadi young entrepreneur, dimana diperoleh bahwa mahasiswa yang berminat menjadi wirausaha hanya sebanyak $28 \%$, sedangkan yang tidak berminat menjadi wirausaha sebanyak $72 \%$. Penelitian ini dilakukan untuk melihat factor apa yang dapat memotivasi mahasiswa untuk menjadi seorang young entrepreneur dilihat dari sisi lingkungan keluarga dan efikasi diri.

Penelitian menggunakan metode kuantitatif yang berjenis kausal eksperimental, dimana penelitian ini menganalisis pengaruh dan hubungan antar variabel satu dengan yang lainnya. Pertanyaan penelitian dibangun berdasarkan tiga operasional variabel, yakni Lingkungan Keluarga, Efikasi Diri, dan Motivasi menjadi seorang young entrepreneur. Penyebaran pertanyaan penelitian dilakukan secara daring, disebar kepada mahasiswa yang masih melakukan studi pada jenjang strata-1, dan diperoleh sebanyak 329 responden.

Digunakan aplikasi SEM PLS pada alat pengujian dan analisis, hasil penelitian menunjukkan bahwa Lingkungan Keluarga, dan Efikasi Diri berpengaruh secara positif, signifikan terhadap motivasi menjadi young entrepreneur. Pada pengujian original sample, diperoleh nilai T Statistic variabel efikasi diri lebih besar daripada variabel lingkungan keluarga. Sehingga, hal ini menunjukkan bahwa peran variabel efikasi diri dalam memotivasi mahasiswa untuk menjadi seorang young entrepreneur lebih besar daripada peran lingkungan keluarga. Selain itu, indikator-indikator yang diujikan pada penelitian ini dapat menjadi masukan kepada para penyelenggara Pendidikan khususnya perguruan tinggi untuk lebih berperan aktif dalam memotivasi mahasiswa agar terdorong keinginan kuat didalam dirinya untuk membuka lapangan kerja ketika lulus kelak.
\end{abstract}

Kata kunci : Lingkungan Keluarga, Efikasi Diri, Motivasi Menjadi Young Entrepreneur

\begin{abstract}
The open unemployment rate (TPT) for university graduates with a bachelor's degree is becoming increasingly concerning, owing largely to an increase in the workforce that has not been fully absorbed by employment. The first observations were made on 50 students who were interviewed about their interest and motivation to become young entrepreneurs. It was discovered that only $28 \%$ of students were interested in becoming entrepreneurs, while $72 \%$ were not. The purpose of this study was to determine what factors, in terms of family environment and selfefficacy, can motivate students to become young entrepreneurs.

This study employs a quantitative method of causal experimental design to determine the influence and relationship between two variables. The research questions were developed using three operational variables: family environment, self-efficacy, and motivation to pursue a career as a young entrepreneur. The research questions were distributed online to students still enrolled at the strata-1 level, and a total of 329 respondents were obtained.

The PLS-SEM application is used to conduct testing and analysis. The study's findings indicate that Family Environment and Self-Efficacy both have a positive, significant effect on motivation to become a young entrepreneur. In the original sample, the T statistic for self-efficacy
\end{abstract}


was greater than the T statistic for the family environment. Thus, this demonstrates that the selfefficacy variable plays a larger role in motivating students to become young entrepreneurs than the family environment does. Additionally, the indicators examined in this study can be used to motivate education providers, particularly universities, to take a more proactive role in motivating students to be motivated by a strong desire to pursue employment opportunities upon graduation.

Keywords : Family Environment, Self-Efficacy, Motivation to Become a Young Entrepreneur

\section{PENDAHULUAN}

Berdasarkan (Oebadillah, 2020) dikutip dari pernyataan Arif Patrick Rahman selaku Chairman Endevour Indonesia, bahwa entrepreneur merupakan kunci agar Indonesia bisa menjadi negara maju, dimana salah satu syarat menjadi negara maju adalah jumlah entrepreneurnya mencapai minimal $14 \%$ dari jumlah penduduk. Sedangkan, saat ini pengusaha di Indonesia baru sekitar 3\%, hal ini menjadi potensi yang sangat besar agar dapat dioptimalkan untuk mendorong Indonesia menjadi negara maju. Melihat fakta ini, adalah salah satu andil yang dapat dilakukan sebagai dosen atau tenaga pendidik yaitu dengan mempersiapkan mahasiswa-mahasiswa agar mau dan mampu menjadi young entrepreneur yang mana jangka panjangnya dapat berperan sebagai agen perubahan dalam memajukan negara Indonesia.

Fenomena lain yang terjadi, melihat data dari Badan Pusat Statistik (BPS) yang mencatat bahwa penduduk usia kerja di Indonesia perbulan Februari 2020 adalah sebanyak 199,4 juta penduduk. Jika dibandingkan dengan jumlah penduduk Indonesia pada tahun 2020, yang tercatat sebanyak 270,20 juta jiwa maka sebesar $73,79 \%$ penduduk Indonesia merupakan penduduk yang berada pada usia kerja. Hal ini dapat dikatakan sebagai bonus demografi untuk Indonesia. (Nerissa Arviana, 2021) Banyak orang sepakat bahwa bonus demografi adalah window of opportunity atau kesempatan, berbagai manfaat yang bisa didapatkan ialah menaikkan produk domestik bruto (PDB) karena jumlah masyarakat usia produktif lebih banyak. Selain itu, terjadi peningkatan tabungan masyarakat dan tabungan sosial yang tentu saja memicu pertumbuhan ekonomi dan pembangunan Indonesia. Manfaat bonus demografi lainnya adalah membuat beban hidup menjadi lebih ringan, sebab penduduk usia nonproduktif yang harus ditanggung penduduk usia produktif lebih sedikit. Hal ini dapat dikatakan sebagai bonus demografi bagi Indonesia dan harus dapat termanfaatkan sebaik mungkin untuk kemajuan negara.

Namun, bak pedang bermata dua dimana bonus demografi juga menjadi tantangan bagi Indonesia, karena jika tidak termanfaatkan dengan baik, bayang-bayang akan pengangguran semakin besar bagi warga di usia produktif. Menteri Kordinator Perekonomian Airlangga Hartanto mengungkapkan sebanyak 29,12 juta orang di Indonesia membutuhkan lapangan pekerjaan baru. pada tahun 2019. Pengangguran terbuka (TPT) lulusan universitas dengan rentang Pendidikan s1 hingga s3 mencapai 737.000 orang, kepala BPS mengungkapkan bahwa pengangguran terjadi karena bertambahnya angkatan kerja yang tidak terserap sepenuhnya oleh lapangan pekerjaan. Entrepreneur atau wirausaha dapat menjadi jawaban dari berbagai fenomena yang diungkapkan sebelumnya, berwirausaha dapat membantu negara untuk berkembang secara ekonomi. Mengurangi jumlah pengangguran, juga dapat meningkatkan jumlah pendapatan pajak negara. Dengan berwirausaha, masyarakat dapat menjadi mandiri, tidak tergantung pada gaji meskipun wirausaha sendiri adalah profesi yang penuh resiko.

Observasi awal yang dilakukan, rendahnya motivasi berwirausaha pada mahasiswa diakibatkan dari kurangnya kepercayaan diri mahasiswa untuk berwirausaha dengan 
bermacam alasan, seperti adanya rasa takut bahwa usahanya akan rugi, berwirausaha itu sulit, membutuhkan modal besar, memiliki resiko yang besar. 50 mahasiswa diwawancarai tentang minat dan motivasi menjadi seorang young entrepreneur, dimana berdasarkan hasil wawancara diperoleh bahwa mahasiswa yang berminat menjadi wirausaha sebanyak $28 \%$, sedangkan yang tidak berminat menjadi wirausaha sebanyak $72 \%$. Lebih lanjut, dari 14 mahasiswa yang berminat untuk berwirausaha terdapat faktor yang mempengaruhi motivasi mahasiswa untuk berwirausaha, di antaranya lingkungan social atau pergaulan sebanyak 39\%, kebutuhan mahasiswa sebesar 36\%, faktor dukungan dari keluarga sebesar 19\%, dan lain-lain sebanyak 6\%. Hasil Observasi awal ini sejalan dengan kekhawatiran Kementerian Pendidikan dan Kebudayan Republik Indonesia tentang ketenagakerjaan pasca melaksanakan perkuliahan pada perguruan tinggi sehingga Pemerintah dalam hal ini kemeterian Pendidikan dan kebudayaan menetapkan Peraturan Menteri Pendidikan dan Kebudayaan Nomor 22 tahun 2020 tentang Rencana Strategis Kementerian Pendidikan dan Kebudayaan Tahun 2020-2024 (Berita Negara Republik Indonesia Tahun 2020 Nomor 555), dituangakan dalam Indikator Kinerja Utama (IKU) Point satu (1) lulusan Perguruan Tinggi mendapatkan pekerjaan yang layak terdiri dari pekerjaan, studi lanjut dan kewirausahaan.

(Suryana \& Bayu, 2012) menyebutkan bahwa faktor yang dapat mendorong seseorang berwirausaha dapat dipengaruhi oleh faktor internal dan faktor eksternal. Faktor internal adalah faktor yang berasal dari dalam diri seseorang dapat berupa sifatsifat personal, sikap, keyakinan, kemauan dan kemampuan individu yang dapat memberi kekuatan individu untuk berwirausaha. Sedangkan faktor eksternal adalah faktor yang berasal dari luar diri seseorang yang dapat berupa unsur dari lingkungan sekitar seperti lingkungan keluarga, lingkungan dunia usaha, lingkungan fisik, lingkungan sosial ekonomi. Lingkungan keluarga adalah lingkungan eksternal pertama yang diperoleh seorang anak dalam hidupnya, pada lingkungan ini salah satunya ayah atau ibu akan mempengaruhi anaknya mengenai masa depannya khususnya dalam pemilihan lapangan pekerjaan yang akan dipilih. Semakin orang tua memberikan dorongan atau pengaruh unuk anaknya dalam berwirausaha, maka anak akan cenderung berminat dan menentukan pilihan sebagai wirausaha. Begitu pula sebaliknya, apa bila orang tua memberikan larangan atau tidak ada dukungan kepada anak untuk menjadi wirausaha, maka akan menjadi sebuah hambatan bai anak untuk berwirausaha.

Inspirasi dan Dukungan Berwirausaha (Hisrich et al., 2017) mengatakan bahwa hubungan orang tua secara keseluruhan dengan anak, terlepas dari apakah orang tuanya pengusaha, maupun tidak, mungkin yang merupakan aspek paling penting dari lingkungan keluarga anak adalah dalam membangun keinginan untuk aktivitas kewirausahaan dalam individu. Orang tua pengusaha harus mendukung dan mendorong kemandirian, prestasi, dan tanggung jawab. Inspirasi untuk berwirausaha dapat diberikan langsung oleh orang tua, atau dapat juga melalui model yang dihadirkan orang tua. Dukungan untuk berwirausaha dapat berupa dukungan moril kesempatan, kepercayaan, pemberian ide/pemikiran), atau dukungan materiil dengan memberikan modal, penyediaan alat/perlengkapan usaha atau lokasi/tempat usaha. Patel (2007:75) mengatakan bahwa anak-anak telah memiliki tanggung jawab dalam keluarga yang besar sejak masih kecil dan telah diberi peluang untuk berperan dan terlibat dalam kegiatan kewirausahaan yang ada dalam keluarga. Hal ini terjadi antara lain karena desakan kebutuhan finansial keluarga, namun orang tua dapat sekaligus memberi kesempatan kepada anak-anak untuk mengembangkan keterampilan dan belajar untuk menerima dan memahami tanggung jawab. Situasi seperti ini akan membekali anak dengan 


\section{AkMen \\ Volume 18 Nomor 3 Desember 2021 \\ Hal. $331-342$ \\ e-ISSN : 2621-4377 \& p-ISSN : 1829-8524 \\ Hbmepage: https//e-jurnal.nobel.acid/index.php/akmen}

keterampilan, pola pikir, keyakian dan nilai-nilai yang diperlukan untuk menjadi pengusaha yang sukses, serta memiliki pengaruh pada perkembangan karakteristik psikologis kewirausahaan individu sejak usia dini.

Selain lingkungan keluarga ada faktor lain yang dapat mempengaruhi motivasi dan intensi berwirausaha yaitu efikasi diri. Ada beberapa pengertian efikasi diri - self efficacy sejak pertama kali dikenalkan oleh (Bandura, 1989) yang disebutkan sebagai keyakinan seseorang tentang kemampuannya, yang kemudian berkembang sehingga ada yang mengartikan sebagai kompetensi diri seeseorang untuk melakukan suatu tugas dan menghadapi kendala yang terjadi. (Greenberg \& A.Baron, 2003) menyebutkan bahwa efikasi ialah sebagai cara individu berperilaku dalam situasi tertentu berdasarkan keyakinan untuk melatih sejumlah ukuran pengendalian terhadap fungsi. Sedikit kesalahan dapat membawa bentuk kerugian yang luar biasa. (Alwisol, 2004) Efikasi diri berhubungan dengan keyakinan bahwa diri memiliki kemampuan melakukan tindakan yang diharapkan. Efikasi adalah penilaian diri, apakah dapat melakukan tindakan yang baik atau buruk, tepat atau salah, bisa atau tidak bisa mengerjakan sesuai dengan yang dipersyaratkan. Efikasi tidak sama dengan aspirasi (citacita) karena aspirasi menggambarkan sesuatu yang ideal yang seharusnya dapat dicapai sedangkan efikasi menggambarkan penilaian tentang kemampuan diri. Sedangkan ekspektasi hasil adalah perkiraan atau estimasi diri bahwa tingkah laku yang dilakukan diri itu akan mencapai hasil tertentu.

Efikasi diri atau Self-efficacy merupakan penilaian seseorang terhadap dirinya sendiri atau tingkat keyakinan mengenai seberapa besar kemampuannya dalam mengerjakan suatu tugas tertentu untuk mencapai hasil tertentu (Tschannen-Moran \& Hoy, 2007). Ada kalanya, seseorang tidak berkeinginan untuk melakukan sesuatu pekerjaan karena tidak memiliki keyakinan bahwa dirinya mampu dan akan berhasil melakukan hal tersebut. Padahal menurut (Kickul, 2007) mengatakan bahwa self-efficacy merupakan salah satu diantara berbagai pengaruh kognitif sosial pada aspirasi karir anakanak, dan self-efficacy akademik memiliki efek langsung terkuat. Lebih lanjut selfefficacy dinyatakan andal dalam memprediksi lingkup pilihan karir, kepentingan kerja, keuletan pada bidang yang sulit dan efektivitas pribadi. Orang bertingkah laku dalam situasi tertentu tergantung kepada resiprokal antara lingkungan dengan kondisi kognitif, khususnya faktor kognitif yang berhubungan dengan keyakinannya bahwa dia mampu atau tidak mampu melakukan tindakan yang memuaskan.

Setiap individu mempunyai keinginan dan minat yang berbeda,dengan perbedaan individu tersebut menyebabkan keinginan dan minat wirausaha bagi mahasiswa berbeda-beda. Ada yang memang memiliki keinginan dan minat yang besar terhadap wirausaha tapi disisi lain banyak juga dari mereka yang lebih memilih berkerja menjadi pegawai. Perbedaan minat ini dapat terjadi karena banyaknya faktor yang mempengaruhi minat mahasiswa ekonomi terhadap kewirausahaan diantaranya adalah dorongan - motivasi lingkungan dan keyakinan dari dalam diri sendiri untuk menjadi wirausaha. Motivasi menurut (Handoko, 2001) ialah suatu keadaan dalam pribadi orang yang mendorong individu untuk melaksanakan aktivitas tertentu guna mencapai tujuan usahanya. Menurut (Drucker, 2000) "Dengan memulai usaha baru, kecil dan milik sendiri, serta sekaligus menjalankan sendiri usaha itu". Menekankan suatu usaha sebagai milik sendiri warausaha kecil dan dilakukan sendiri. Sebagai orang yang melakukan usaha wirausaha ; bukanlah sosok manusia yang sepenuhnya rasional, yang hanya terdorong untuk mencari laba dan hanya mengambil keputusan atas dasar perhitungan rasional semata. 
Penelitian (Puspitaningsih, 2017) menunjukkan bahwa efikasi diri tidak berpengaruh terhadap motivasi, efikasi diri berpengaruh terhadap minat, motivasi berpengaruh terhadap minat wirausaha, motivasi tidak berfungsi sebagai variabel mediasi pada pengaruh efikasi dan motivasi berfungsi sebagai variabel yang memediasi pada pengetahuan kewirausahaan terhadap minat wirausaha. Berbeda pada hasil yang dilakukan oleh (Aini et al., 2015) yang menunjukkan bahwa efikasi diri berpengaruh langsung terhadap motivasi berwirausaha, lingkungan keluarga berpengaruh langsung terhadap motivasi berwirausaha, dan lingkungan keluarga berpengaruh langsung terhadap efikasi diri. Sementara, (Pratiwi \& Wardana, 2016) menunjukan bahwa ada pengaruh yang positif dan signifikan dari faktor internal dan faktor eksternal terhadap minat berwirausaha secara parsial.

Melihat fenomena, peluang, dan gap research yang telah disampaikan sebelumnya, maka penelitian ini ditujukan untuk melihat adanya hubungan antara lingkungan keluarga, efikasi diri, dan motivasi pada mahasiswa FEB UMI untuk menjadi seorang young entrepreneur. Penelitian dilakukan pada Fakultas Ekonomi dan Bisnis UMI mengingat pada fakultas tersebut telah menyelenggarakan mata kuliah kewirausahaan yang telah masuk pada tahun ketiga penyelenggaraan sebagai mata kuliah wajib setiap mahasiswa FEB. Berdasar dari latar belakang yang disampaikan maka, judul penelitian yang diangkat adalah Peran Lingkungan Keluarga dan Efikasi Diri yang Memotivasi Mahasiswa FEB UMI untuk menjadi Young Entreprenuer. Kerangka penelitian yang diajukan adalah sebagai berikut:

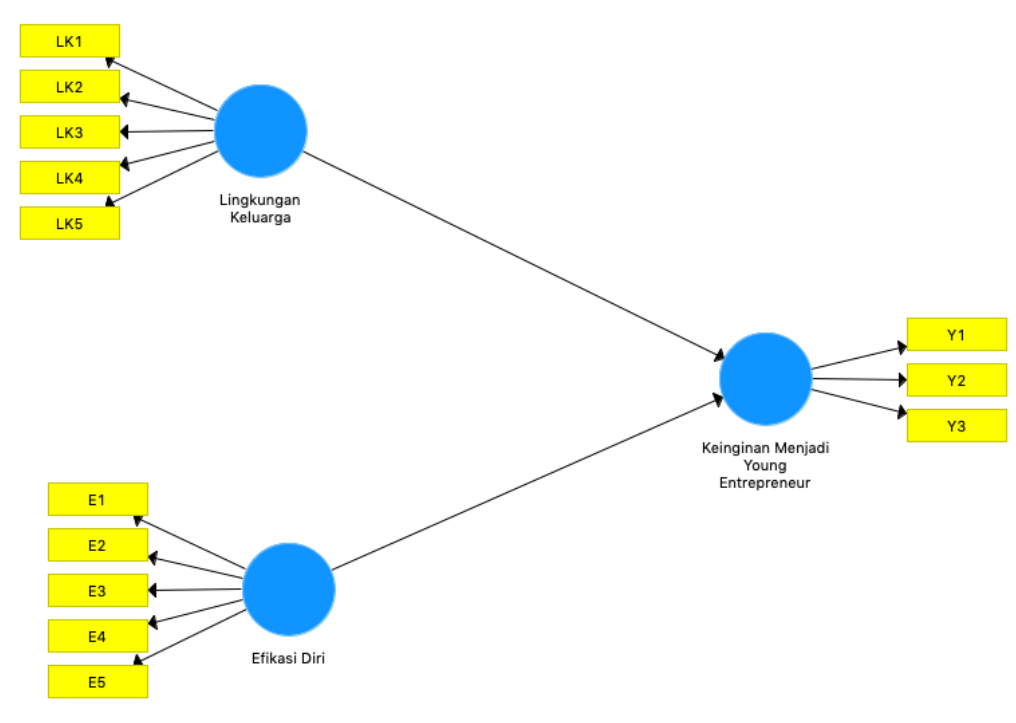

Gambar 1 Kerangka Penelitian

Hipotesis ; Lingkungan keluarga berpengaruh terhadap Motivasi Menjadi Young Entrepreneur; Efikasi diri berpengaruh terhadap Motivasi Menjadi Young Entrepreneur; Lingkungan keluarga dan Efikasi diri berpengaruh Bersama-sama terhadap motivasi mahasiswa menjadi Young Entrepreneur

\section{METODE PENELITIAN}

Penelitian ini diklasifikasikan sebagai penelitian kausal eksperimental, dimana penelitian ini menganalisis pengaruh dan hubungan antar variabel yang satu dengan yang lain. Pada studi eksperimental peneliti mengendalikan setidaknya satu variabel bebas dan 
mengamati akibat yang terjadi kepada satu atau lebih variabel terikat, (Kuncoro, 2013). Guna menjawab perumusan masalah penelitian yang sudah ditetapkan, peneliti memilih pendekatan penelitian. Pendekatan ini disesuaikan dengan kebutuhan pencarian jawaban atas pertanyaan penelitian (perumusan masalah). Penelitian ini mencakup hal-hal yang dapat dilakukan peneliti mulai dari membuat hipotesis dan implikasinya secara operasional sampai pada analisa data yang selanjutnya disimpulkan dan diberikan saran.

Metode Analisis Data yang digunakan untuk pembahasan dalam penelitian ini adalah: Uji Kualitas Data, menggunakan dua pengujian, yakni uji validitas dan uji reliabilitas. Penulis menggunakan bantuan program software Smart PLS versi 3.0 untuk memperoleh hasil yang terarah.Menurut (Abdillah \& Jogiyanto, 2011) Penggunaan SEM berbasis PLS yaitu dengan memaksimalkan varian yang dijelaskan pada variabel laten endogen (variabel tergantung) dengan analisis tambahan yaitu penilaian kualitas data yang didasarkan pada karakteristik model pengukuran. Penggunaan PLS dalam penelitian ini didasarkan pada beberapa pertimbangan yaitu (1) PLS dapat digunakan untuk menguji efek prediksi hubungan antar variabel laten, (2) PLS tidak mensyaratkan data terdistribusi normal (indikator dengan skala kategori, ordinal, interval sampai ratio dapat digunakan pada model yang sama), sampel tidak harus besar (Ghozali \& Latan, 2015) dan pendekatan regresi (analisis path) dalam PLS-SEM yang berbasis varian lebih cocok digunakan dibandingkan dalam SEM yang berbasis kovarian seperti AMOS dan LISREL.

Model evaluasi PLS dilakukan dengan menilai outer model dan inner model. Evaluasi Model Pengukuran (Outer Model), disebut pula dengan evaluasi model pengukuran dilakukan untuk menilai validitas dan reliabilitas model. Model pengukuran dengan indikator refleksif dievaluasi dengan convergent dan discriminant validity untuk indikator pembentuk konstruk laten, serta melalui composite reliability dan cronbach alpha untuk item indikatornya (Ghozali \& Latan, 2015). Validitas konvergen berhubungan dengan prinsip bahwa pengukur-pengukur (manifest variabel) dari suatu konstruk seharusnya berkorelasi tinggi. Uji validitas konvergen indikator refleksif dapat dilihat dari nilai loading factor untuk setiap konstruk. Kriteria penilaian uji validitas convergent dan discriminant dapat dilihat pada Tabel.

Tabel 1. Uji Validitas

\begin{tabular}{|c|c|c|}
\hline Validitas & Parameter & Kriteria penilaian \\
\hline \multirow{2}{*}{$\begin{array}{l}\text { Validitas } \\
\text { Konvergen }\end{array}$} & Loading Factor & $>0,30$ \\
\hline & $\begin{array}{l}\text { AVE (Average } \\
\text { variance } \\
\text { extracted) }\end{array}$ & $>0,50$ \\
\hline \multirow{2}{*}{$\begin{array}{l}\text { Validitas } \\
\text { Diskriminan }\end{array}$} & Cross Loading & $\begin{array}{l}\text { Diharapkan setiap blok } \\
\text { indikator memiliki loading } \\
\text { lebih tinggi untuk setiap } \\
\text { variabel laten yang diukur } .\end{array}$ \\
\hline & $\begin{array}{l}\text { Akar AVE dan } \\
\text { korelasi } \\
\text { Antar konstruk } \\
\text { laten }\end{array}$ & $\begin{array}{c}\text { Akar AVE > korelasi antar } \\
\text { konstruk laten }\end{array}$ \\
\hline \multicolumn{2}{|c|}{ Parameter } & Kriteria Penilaian \\
\hline \multicolumn{2}{|c|}{ Composite Reliability } & $>0,60$ \\
\hline \multicolumn{2}{|c|}{ Cronbach's Alpha } & $>0,70$ \\
\hline
\end{tabular}


Selain uji validitas, pengukuran model juga dilakukan untuk menguji keakuratan (reliabilitas) suatu konstruk. Uji reliabilitas dilakukan untuk membuktikan akurasi, konsistensi, dan ketepatan instrument dalam mengukur konstruk. Uji reliabilitas suatu konstruk dengan indikator refleksif dapat dilakukan dengan dua cara, yaitu Composite Reliability dan Cronbach's Alpha. Penggunaan Cronbach's Alpha untuk menguji reliabilitas konstruk akan memberikan nilai yang lebih rendah (under estimate) sehingga lebih disarankan untuk menggunakan composite reliability dalam menguji reliabilitas suatu konstruk. Kriteria penilaian untuk uji reliabilitas konstruk dengan indikator refleksif dapat dilihat pada Tabel di atas.

\section{HASIL DAN PEMBAHASAN}

Hasil

Hasil uji deskripsi pada penelitian ini adalah sebagai berikut ;

Table 1 Measurement Table

\begin{tabular}{llcc}
\hline \multicolumn{1}{c}{ Measurement } & Mean & $\begin{array}{c}\text { Std. } \\
\text { Error }\end{array}$ & $\begin{array}{c}\text { Std. } \\
\text { Dev }\end{array}$ \\
\hline 1. Lingkungan Keluarga (LK) \\
$\circ \begin{array}{l}\text { (LK.1) Orang tua mengajari saya tentang } \\
\text { bisnis }\end{array}$ & 4.030 & 0,044 & 0,895 \\
$\circ \quad \begin{array}{l}\text { (LK.2) Orang tua mengarahkan saya } \\
\text { menjadi pengusaha sukses }\end{array}$ & 4.237 & 0,033 & 0,925 \\
$\circ \quad \begin{array}{l}\text { (LK.3) Orang tua saya bangga jika saya } \\
\quad \begin{array}{l}\text { menjadi pengusaha } \\
\text { (LK.4) Keluarga memberikan saya dorongan }\end{array}\end{array}$ & 4.505 & 0,046 & 0,772 \\
$\quad \begin{array}{l}\text { dan fasilitas penuhuntuk menjadi seorang } \\
\text { pengusaha } \\
\text { (LK.5) Keluarga siap membantu segala } \\
\text { keperluan saya dalam membuka usaha }\end{array}$ & 3.884 & 0,050 & 1,007 \\
& 3.936 & 0,044 & 0,932
\end{tabular}

\section{Efikasi Diri (E)}

- (E.1) Saya berusaha mendapatkan hasil yang maksimal di setiap tugas dan pekerjaan

$4.696 \quad 0,036 \quad 0,603$

- (E.2) Saya yakin mampu mengatasi sulitnya mengembangkan usaha

$4.225 \quad 0,044 \quad 0,775$

- (E.3) Gambaran tentang peluang usaha yang cukup tinggi menguatkan pikiran dan perasaan saya untuk lebih ulet, tekun dan

$4.416 \quad 0,049 \quad 0,735$
berusaha keras

- (E.4) Saya yakin akan mendapatkan apa yang diinginkan asalkan disertai dengan usaha $4.766 \quad 0,047 \quad 0,548$ keras

- (E.5) Saya yakin kesuksesan berwirausha tidak muncul secara tiba-tiba,diperlukan namanya proses 


\section{AkMen \\ Volume 18 Nomor 3 Desember 2021 \\ Hal. $331-342$ \\ e-ISSN : 2621-4377 \& p-ISSN : 1829-8524 \\ Homepage: https//e-jurnal.nobel.acid/index.php/akmen}

3. Motivasi Menjadi Young Entrepreneur (Y)

- (Y.1) Saya memilih menjadi seorang wirausahawan karena ingin membuka lapangan pekerjaan

- (Y.2) Saya memilih berwirausaha karena saya suka mengatur jadwal bekerja saya sendiri

$\begin{array}{lll}4.292 & 0,042 & 0,832 \\ 4.596 & 0,039 & 0,742 \\ 4.632 & 0,043 & 0,667\end{array}$

- (Y.3) Berwirausaha mengajarkan saya dalam hal kemandirian

Selain itu, dalam menyelidiki konfigurasi jalur simetris, metode analisis data yang digunakan adalah analisis regresi dan korelasi. Tahap pengujian penelitian ini melalui tiga tahap yaitu pertama, validitas dan reliabilitas konfigurasi konstruk; hubungan yang menjelaskan pengaruh langsung; dan ketiga, hubungan yang menunjukkan dampak dari semua variabel yang diukur. Seperti yang dapat kita lihat dari tabel di bawah ini, pengujian analisis statistik menunjukkan bahwa dalam pengujian kelayakan model dinyatakan valid dan reliabel. Indikator konstruk Lingkungan Keluarga (LK) yang paling dominan dibentuk oleh; (LK.4 = 0,840) Keseluruhan item manifes Lingkungan Keluarga (LK) yang handal membentuk variabel yang dibangun sebesar 0,275. Kedua, Indikator konstruk Efikasi Diri $(E)$ yang paling dominan dibentuk oleh indikator $($ E.4 $=0.820)$ Keseluruhan item manifes Efikasi Diri (E) yang reliabel membentuk variabel konstruk sebesar 0,534. Ketiga, Indikator konstruk Motivasi menjadi Young Entrepreneur (Y) yang paling dominan dibentuk oleh; $(\mathrm{Y} .3=0,869)$ Item manifest Kepuasan $(\mathrm{S})$ yang reliabel secara keseluruhan membentuk variabel konstruk sebesar 0,481.

Untuk lebih jelasnya dapat dilihat pada table berikut;

Table 2 Tabel Hasil Uji Analisis

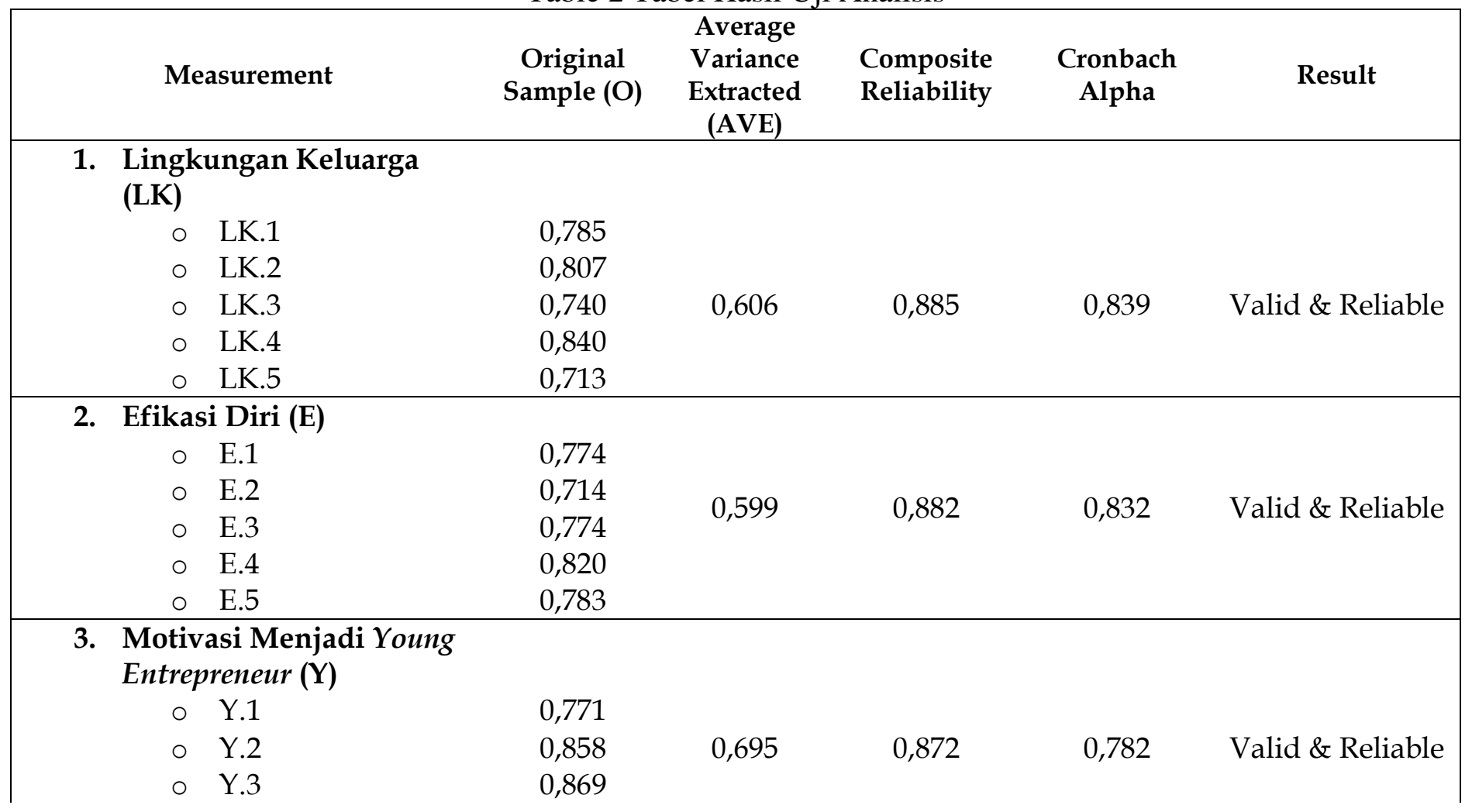




\section{AkMen}

Volume 18 Nomor 3 Desember 2021

Hal. $331-342$

e-ISSN : 2621-4377 \& p-ISSN : 1829-8524

Hbmepage: https//e-jurnal.nobel.acid/index.php/akmen

\begin{tabular}{|c|c|c|c|c|c|c|}
\hline \multicolumn{7}{|c|}{$\begin{array}{c}\text { Normality Test } \\
\text { Kolmogorov-Smirnov } Z=0,551 \\
\text { Asymp Sig }=0,921\end{array}$} \\
\hline \multicolumn{7}{|c|}{ Hypothesis Test } \\
\hline Direct Test & $\begin{array}{l}\text { Original } \\
\text { Sample } \\
\text { (O) }\end{array}$ & $\begin{array}{c}\text { Sample } \\
\text { Mean (M) }\end{array}$ & STDEV & $\begin{array}{l}\text { T Statistics } \\
(\mid \mathrm{O} / \mathrm{STDE} \\
\mathrm{V} \mid)\end{array}$ & $\begin{array}{c}\mathbf{P} \\
\text { Values }\end{array}$ & Sign. \\
\hline $\begin{array}{c}\text { Lingkungan Keluarga (LK) } \rightarrow \\
\text { Motivasi Menjadi Young } \\
\text { Entrepreneur }(\mathrm{Y})\end{array}$ & 0,275 & 0,533 & 0,055 & 5,049 & 0,000 & $\begin{array}{c}\text { Signif } \\
\text { icant }\end{array}$ \\
\hline $\begin{array}{c}\text { Efikasi Diri }(\mathrm{E}) \rightarrow \text { Motivasi } \\
\text { Menjadi Young Entrepreneur }(\mathrm{Y})\end{array}$ & 0,534 & 0,273 & 0,054 & 9,652 & 0,000 & $\begin{array}{c}\text { Signif } \\
\text { icant }\end{array}$ \\
\hline \multicolumn{4}{|c|}{$\begin{array}{l}\text { R Test } \\
\text { R Square }\end{array}$} & \multicolumn{3}{|c|}{ R Square Adjusted } \\
\hline $\begin{array}{l}\text { Motivasi Menjadi Young } \\
\text { Entrepreneur (Y) }\end{array}$ & \multicolumn{3}{|c|}{0,481} & \multicolumn{3}{|c|}{0,478} \\
\hline
\end{tabular}

Selanjutnya pada pengujian hipotesis seperti yang dijelaskan pada Tabel 2. Hubungan searah ditemukan dengan hasil yang signifikan, Uji hipotesis menemukan bahwa untuk semua variabel yang digunakan dalam model terdapat hubungan yang positif dan signifikan. Nilai t tabel yang diperoleh dengan melihat kesalahan tanda 0,05 dengan $n=329$ adalah 1,967. Sehingga, dapat disimpulkan bahwa setiap variabel yang diukur dapat dinyatakan berpengaruh positif. Hasil pengujian koefisien jalur juga menunjukkan bahwa variabel Efikasi Diri (E) memiliki pengaruh langsung paling besar terhadap Motivasi Menjadi Young Entrepreneur (Y) yaitu sebesar 9,652.

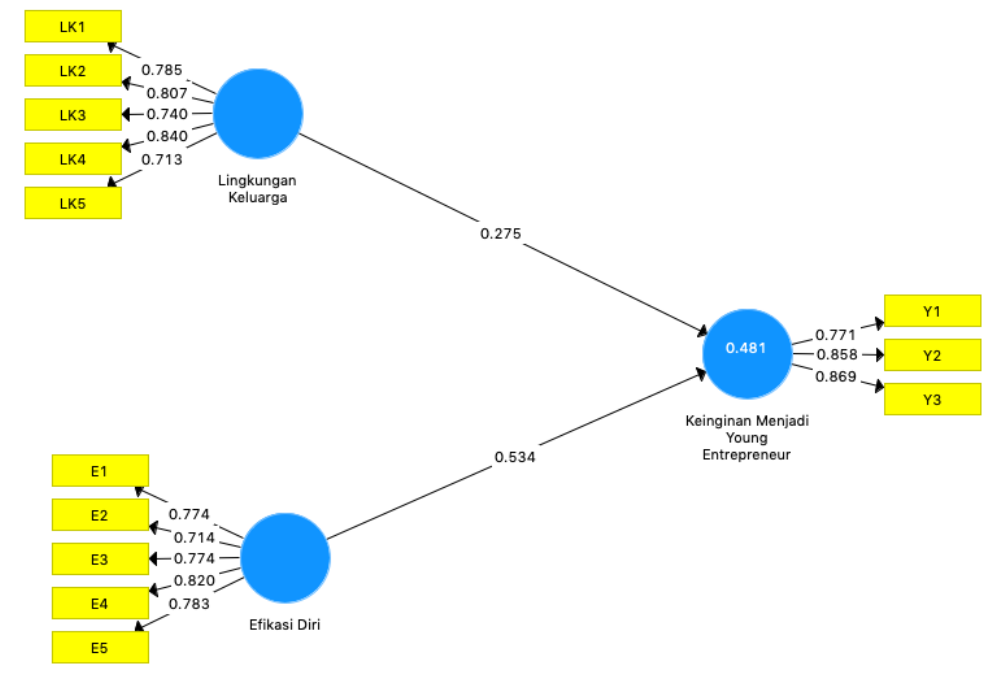

Gambar 2. Hasil Uji SEM PLS

\section{PEMBAHASAN}

Pembahasan ini difokuskan pada keputusan-keputusan yang dihasilkan dari pengujian hipotesis, sebagai upaya menjawab rumusan masalah penelitian. Berikut ini diuraikan hasil analisis pengolahan data statistik dengan menggunakan teknik SmartPLS 3. Lingkungan Keluarga didefinisikan sebagai lingkungan social terdekat 
dari seorang wirausaha, yang sangat besar peranannya dalam membentuk karakter, termasuk karakter wirausaha dari seorang anak. Saroni (2012) mengatakan bahwa lingkungan keluarga mempunyai andil yang sangat besar dalam mempersiapkan anakanak menjadi seorang wirausahawan di masa yang akan datang. Keluargalah yang mula-mula bertanggung jawab atas pendidikan anak- anak, sehingga keluarga dapat dikatakan sebagai peletak dasar bagi pola perilaku serta perkembangan pribadi anak

Pengujian hipotesis pertama pada penelitian ini menunjukkan hasil bahwa Lingkungan Keluarga berpengaruh positif dan signifikan terhadap motivasi menjadi seorang young entrepreneur studi pada mahasiswa Fakultas Ekonomi dan Bisnis Universitas Muslim Indonesia. Hal ini dikuatkan oleh indicator yang menyebutkan bahwa "Keluarga memberikan saya dorongan dan fasilitas penuh untuk menjadi seorang pengusaha". Sehingga, untuk memberikan motivasi yang tinggi terhadap mahasiswa dalam membentuk motivasinya untuk menjadi seorang young entrepreneur, diharapkan keluarga mampu memberi dukungan baik dorongan dan fasilitas penuh untuk menjadi seorang pengusaha. Hasil penelitian ini didukung dari penelitian yang dilakukan oleh Berbeda pada hasil yang dilakukan oleh (Aini et al., 2015) yang menunjukkan bahwa efikasi diri berpengaruh langsung terhadap motivasi berwirausaha, lingkungan keluarga berpengaruh langsung terhadap motivasi berwirausaha, dan lingkungan keluarga berpengaruh langsung terhadap efikasi diri. Serta penelitian dari (Pratiwi \& Wardana, 2016) menunjukan bahwa ada pengaruh yang positif dan signifikan dari faktor internal dan faktor eksternal terhadap minat berwirausaha secara parsial.

Efikasi diri merupakan pertama kali diungkapkan oleh Bandura, menurut Bandura dalam (Alwisol, 2004) efikasi diri atau Self Effication adalah keyakinan atau harapan diri. Sedangkan harapan hasilnya adalah ekspektasi dari hasil. Efikasi diri berhubungan dengan keyakinan bahwa diri memiliki kemampuan melakukan tindakan yang diharapkan. Efikasi adalah penilaian diri, apakah dapat melakukan tindakan yang baik atau buruk, tepat atau salah, bisa atau tidak bisa mengerjakan sesuai dengan yang dipersyaratkan. Efikasi tidak sama dengan aspirasi (cita-cita) karena aspirasi menggambarkan sesuatu yang ideal yang seharusnya dapat dicapai sedangkan efikasi menggambarkan penilaian tentang kemampuan diri.

Pada penelitian ini efikasi diri mampu mendukung motivasi pada mahasiswa Fakultas Ekonomi dan Bisnis, Universitas Muslim Indonesia dalam mendukung untuk menjadi young entrepreneur. Indikator yang paling berperan dalam variabel efikasi diri ialah "Saya yakin akan mendapatkan apa yang diinginkan asalkan disertai dengan usaha keras". Sehingga untuk membangun motivasi dalam menjadi seorang young entrepreneur, diharapkan setiap mahasiswa untuk tekun berusaha dalam merintis usaha yang akan dikembangkannya. Untuk meningkatkan motivasi mahasiswa menjadi seorang young entrepreneur, dibutuhkan kontribusi beberapa pihak baik dari keluarga, lingkungan universitas, bahkan kepercayaan diri dari mahasiswa. Motivasi menjadi seorang young entrepreneur akan meningkat jika mampu meningkatkan dukungan dari lingkungan keluarga, serta keyakinan dalam diri sendiri.

\section{KESIMPULAN}


Lingkungan keluarga dan Efikasi Diri dalam penelitian ini terbukti berpengaruh positif dan signifikan terhadap motivasi untuk menjadi seorang young entrepreneur pada Mahasiswa Fakultas Ekonomi dan Bisnis, Universitas Muslim Indonesia. Penelitian ini menunjukkan bahwa variabel-variabel tersebut perlu diperhatikan agar terus berperan dalam meningkatkan motivasi mahasiswa untuk menjadi seorang young entrepreneur. Selain itu, diperlukan komitmen pada beberapa pihak termasuk keluarga, universitas, dan terutama pada diri sendiri.

Penelitian ini hanya dilakukan pada Mahasiswa Fakultas Ekonomi dan Bisnis di Universitas Muslim Indonesia. Sehingga, Hasil, kesimpulan, atau saran yang diberikan tidak mencerminkan hasil umum yang terjadi pada mahasiswa di tempat lainnya. Diperlukan pengujian secara berkala dan terstruktur di setiap objek penelitian lainnya untuk mendapatkan hasil yang valid, hal ini tidak lepas dari keterbatasan setiap penelitian yang dilakukan. Terima kasih.

\section{SARAN}

Diperlukan untuk meningkatkan secara bersama-sama antara Lingkungan Keluarga dan Efikasi Diri dari mahasiswa agar dapat meningkatkan motivasi untuk menjadi seorang young entrepreneur. Bagi penelitian selanjutnya, dapat mengaplikasikan variabel independen lainnya untuk melihat bagaimana pengaruhnya dengan variabel motivasi untuk menjadi seorang young entrepreneur, karena dalam penelitian ini besarnya pengaruh yang diperoleh belum terlalu tinggi dan terdapat satu variabel independen.

\section{DAFTAR PUSTAKA}

Abdillah, \& Jogiyanto. (2011). Partial Least Square (PLS), Alternatif Structural. Equation Modeling (SEM) dalam Penelitian Bisnis. Andi.

Aini, S. N., ES, D. P., \& Saptono, A. (2015). Pengaruh Lingkungan Keluarga dan Efikasi Diri terhadap Motivasi Berwirausaha pada Mahasiswa Fakultas Ekonomi Universitas Negeri Jakarta. Jurnal Pendidikan Ekonomi Dan Bisnis (JPEB), 3(1), 22-50.

Alwisol, A. (2004). Psikologi kepribadian edisi revisi. Jakarta: UMM Press.

Bandura, A. (1989). Regulation of cognitive processes through perceived self-efficacy. Developmental Psychology, 25(5), 729.

Drucker, P. (2000). Knowledge work. In Executive Excellence (Vol. 17, Issue 4). Proquest ABI/INFORM.

Ghozali, I., \& Latan, H. (2015). Partial least squares konsep, teknik dan aplikasi menggunakan program smartpls 3.0 untuk penelitian empiris. Semarang: Badan Penerbit UNDIP.

Greenberg, J., \& A.Baron, R. (2003). Behavior in Organizations. Prentice Hall.

Handoko, T. H. (2001). Manajemen Personalia dan Sumber Daya Manusia Edisi 2. Yogyakarta: BPFE.

Hisrich, R. D., Peters, M. P., \& Shepherd, D. A. (2017). Entrepreneurship. McGraw-Hill Education.

Kickul, J. (2007). Fiona Wilson Jill Kickul Deborah Marlino.

Nerissa Arviana, G. (2021). Bonus Demografi: Definisi, Tantangan, hingga Cara Memanfaatkannya. https://glints.com/id/lowongan/bonus-demografiadalah/\#.YNPSGBMza00

Oebadillah, S. (2020, December 24). Syarat Jadi Negara Maju : Perbanyak Wirausaha. 
https://mediaindonesia.com/ekonomi/371536/syarat-jadi-negara-maju-perbanyakwirausaha

Pratiwi, Y., \& Wardana, I. M. (2016). Pengaruh faktor internal dan eksternal terhadap minat Berwirausaha mahasiswa fakultas ekonomi dan bisnis Universitas udayana. E-Jurnal Manajemen, 5(8), 5215-5242.

Puspitaningsih, F. (2017). Pengaruh Efikasi Diri dan Pengetahuan Kewirausahaan Terhadap Minat Berwirausaha Melalui Motivasi. Jurnal Ekonomi Pendidikan Dan Kewirausahaan, 2(2), 223-235.

Suryana, Y., \& Bayu, K. (2012). Kewirausahaan: Pendekatan Karakteristik Wirausahawan Sukses Ed. 2. Kencana.

Tschannen-Moran, M., \& Hoy, A. W. (2007). The differential antecedents of self-efficacy beliefs of novice and experienced teachers. Teaching and Teacher Education, 23(6), 944-956. 